\title{
ДИСКУРС ФОРМАЛІЗМУ В УКРАЇНІ: ЛІНГВІСТИЧНИЙ АСПЕКТ
}

\author{
ТЕТЯНА КОВАЛЕНКО \\ Горлівський інститут іноземних мов ДВНЗ Донбаський державний \\ педагогічний університет, Донецьк - Україна \\ DYSKURS FORMALIZMU NA UKRAINIE: \\ ASPEKT LINGWISTYCZNY \\ TETIANA KOWALENKO \\ Instytut Języków Obcych w Gorłówce \\ PWZO „Donbaski Państwowy Uniwersytet Pedagogiczny”, \\ Donieck - Ukraina
}

\begin{abstract}
STRESZCZENIE. W artykule została omówiona specyfika dyskursu ukraińskiego formalizmu. Punktem wyjścia była propozycja krytycznej dyskurs-analizy na materiale tekstów B. Jakubskiego, G. Majfeta, M. Semenki, O. Poltorackiego, M. Johansena. Określone zostały narzędzia językowe oraz kierunek polemiki dyskursu ukraińskiego formalizmu z dyskurs-budową nauki jako instytucji społecznej.
\end{abstract}

\section{FORMALISM DISCOURSE IN UKRAINE: LINGUISTIC ASPECT}

\author{
TETIANA KOVALENKO \\ Horlivka Institute of Foreign Languages HSEE "Donbass State \\ Pedagogical University" Donietsk — Ukraine
}

\begin{abstract}
The article is devoted to the studying of discourse of Ukrainian Formalism on the material of B. Jakubski's, G. Majfet's, M. Semenko's, O. Poltoracki's, M. Johansen's texts, applying the method of critical discourse analysis. The linguistic means and vectors of polemics between discourse of Ukrainian Formalism and order of discourse of science as a social institute were outlined.
\end{abstract}

$\Phi$ ормалізм - один із впливових напрямів літературознавства XX ст., що привертав значну увагу дослідників і залишається популярним об'єктом студій і до сьогодні. Незважаючи на те, що формалізму присвячена велика кількість розвідок, в історії і теорії цього феномена досі лишаються лакуни, зокрема бракує досліджень, у яких би осмислювалося функціонування формалізму поза Росією — в Україні, Польщі тощо. Якщо порівнянню польського й російського формалізму була присвячена монографія А. Карча Школа польського формалізму і російський формалізм, то вияви названого явища в українському контексті досліджені доволі слабко (фактично, з українського формалізму маємо лише збірку статей Дискурс формалізму: український контекст ${ }^{2}$ ).

${ }^{1}$ A . Karc z, The Polish Formalist School and Russian Formalism, Rochester, NY 2002.

${ }^{2}$ Дискурс формалізму: украӥнський контекст (Соло триває... нові голоси. Лекиія на пошану С. Павличко), Львів 2004. 
Унікальність формалізму як культурного явища полягає в багатовекторності його проявів, що не вкладаються в суто літературознавчі обшири. Але навіть якщо обмежитися теоретичним виміром формалізму, осмислювати його в полі уявлень про традиційну науку доволі складно. Спроба проаналізувати російський формалізм крізь призму різних наукознавчих методологій привела О. Дмитрієва і Я. Левченка до висновку, що формалізм є радше „соціокультурним набором правил серйозної гри у веселу науку", ніж науковою течію в традиційному розумінні поняття: ,таким чином, формалістська науковість була не стільки сукупністю кодифікованих нормативних методологічних постулатів побудови літературної теорії, скільки соціокультурним набором правил серйозної гри у веселу науку, головними з яких була вірність вихідним принципам іманентного аналізу літературного ряду, ставка на оновлення, продуктивне самопротиріччя та свободу від догм і шаблонів, включаючи власні””. „Реформи" формалізму у сфері літературознавства полягали не лише в характері висловлюваних теоретичних постулатів, але й у самому способі їх виголошення. Особливо помітно це на тлі інших теоретичних напрямів, що беруть початок 3 формалізму й належать до тієї ж наукової парадигми, структуралізму й наратології, для яких характерне дотримання засад наукового дискурсу.

3 перспективи лінгвістики специфіка артикуляції концепцій формалізму грунтовно не досліджувалася. Проте саме особливості висловлювання формалістами власних поглядів могли б дати підстави для ідентифікації формалізму в контекстах, де його прояви були „розпорошені”, зокрема в Україні, адже наявність спільних засад конструювання висловлювань свідчила би про парадигматичність прояву формалізму в українському контексті. Відповідно, актуальність теми статті зумовлена важливістю вивчення лінгвістичної специфіки українського формалізму як для дослідження розвитку формалізму в Україні, так і для глибшого осмислення формалізму як культурного феномена загалом.

Формалізм постав у час активних культурних перетворень і був тісно пов’ язаний з авангардом і соцреалізмом. Осмислюючи специфіку зв'язку між останніми двома феноменами, В. Влодарчик указує, що їх об'єднувало бажання поєднати захоплення мовою висловлювання, вивчення їі специфіки з суспільною чи політичною ангажованістю мистецтва ${ }^{4} .3$ певними корективами це твердження можна було б віднести й до формалізму, представники якого цікавилися закономірностями змін у культурі, потенційними засобами трансформації культурної ситуації. Продуктивним способом простеження „конструктивного” аспекту формалізму є розгляд його дискурсивної специфіки на основі акуалізації методології критичного дискурс-аналізу, що скеровує увагу на відношення між дискурсом, з одного боку, й соціальним та культурним розвитком ${ }^{5}$, го, а сам дискурс тлумачить як такий, що одночасно й створює, й створюється 6 . Критичний дискурс-аналіз спонукає до виділення в процесі будь-якого аналізу двох аспектів дискурсу: комунікативної події (конкретний випадок уживання мови) й дискурс-будови (конфігурація всіх типів дискурсів, що використовуються в соціальному інституті чи соціальній галузі $)^{7}$. Комунікативна подія має

${ }^{3}$ А. Д м и т и ев, Я. Л е вче нко, Наука как прием: ещзе раз о методологическом наследии русского формализма, [в:] „Новое литературное обозрение” 2001, № 50, [в:] Электронный ресурс: http://magazines.russ.ru/nlo/2001/50/dmitr.html (12.09.2013).

${ }^{4}$ W. Wło darc z y k, Socrealizm. Sztuka polska w latach 1950-1954, Paris 1986, s. 127.

${ }^{5}$ В. Й орге н с ен, Дискурс-анализ. Теория и метод, Харьков 2004, с. 109.

${ }^{6}$ Там же, с. 110.

7 Там же, с. 119. 
тривимірну будову: вона складається $з$ тексту, дискурсивної практики й соціальної практики, відповідно, аналіз комунікативної події передбачає характеристику рівня тексту, рівня дискурсивної практики й рівня соціальної практики $^{8}$. Дискурс-будова $є$ потенційно конфліктною конфігурацією дискурсів у межax певного соціального поля 9 , а конкретна дискурсивна практика водночас і відтворює засади дискурс-будови, і „сперечається” 3 ними, вносячи елементи оновлення ${ }^{10}$.

Методологія критичного дискурс-аналізу Н. Феркло, таким чином, дає змогу простежити взаємодію формалізму з наукою як соціальним інститутом шляхом вивчення дискурсивної практики формалізму в межах дискурс-будови науки. 3 причин часової дистанційованості й неможливості здійснення безпосередніх спостережень над дискурсом формалізму, його вивчення можливе лише на підставі дослідження текстів. Для комплексного вивчення дискурсу Н. Феркло пропонує аналізувати сім аспектів текстів, що його презентують: 1) словник (лексичний склад); 2) граматику; 3 ) когезію; 4) структуру тексту; 5) „вплив” висловлювань; 6) „когерентність” текстів; 7) ,інтертекстуальність” та „інтердискурсивність”. За словами дослідника, „разом ці сім позицій утворюють каркас для аналізу текстів, що охоплює аспекти їх продукування та інтерпретації, а також формальні властивості тексту"11.

Фактично, полем вивчення дискурсу, згідно з поглядами Н. Феркло, постає текст, який формує дискурсивну практику, що підтверджується здійсненим дослідником аналізом текстів в одному з розділів його розвідки Дискурс $i$ coųiaльна зміна ${ }^{12}$. Продуктивність поданої схеми аналізу підтверджується тим, що виділені для аналізу аспекти дають змогу простежити характер ключових особливостей інституціональних дискурсів, поміж яких називають: 1) уявлення про соціальну місію інституту; 2) особливу мову, включаючи професійну, яку прийнято вживати під час включення в конкретну інституційну комунікацію; 3) нормативну модель типово-подієвої статусно-рольової комунікації, до реалізації якої змушує конкретний інституційний дискурс; 4) систему базових цінностей, що транслюються через інституціональні комунікації; 5) основні стратегії інституціонального дискурсу; 6) жанри інституціонального дискурсу; 7) прецедентні тексти; 8) типові дискурсні формули ${ }^{13}$.

Для повноцінного вивчення дискурсивної специфіки формалізму водночас необхідна інформація про особливості дискурс-будови науки, синхронної функціонуванню формалізму. Зважаючи на різнорідність текстів, якими репрезентований формалізм в Україні (класичні монографії, статті в альтернативних журналах, пародійні розвідки), конструювати докладний образ дискурс-будови науки 1920-х рр., якій „опонував” формалізм, було би спрощенням і не дало би змоги простежити єдність українського формалізму. 3 іншого боку, методологія дискурс-аналізу дозволяє зосередитись на загальних особливостях дискурсбудови науки як соціального інституту, не входячи в його часову й просторову специфіку.

${ }^{8}$ Там же, с. 122.

${ }^{9}$ Там же, с. 128.

${ }^{10}$ Там же, с. 116.

${ }^{11}$ N. F a i r cl oug h, Discourse and Social Change, Cambridge 1992, p. 75.

${ }^{12} \mathrm{Ibidem}$, P. 169-199.

${ }^{13} \mathrm{O}$. Русакова, В. Русаков, PR-дискурс: теоретико-методологический анализ, Екатеринбург 2008, [в:] Електронний ресурс: http://www.madipi.ru/index.php?option=com_content\&vi ew $=$ article\&id=27\%3apr\&catid=59\%3apr----\&itemid=10\&limitstart=14 (09.10.2013). 
Мета запропонованої статті - окреслити специфіку дискурсу формалізму в Україні в лінгвістичному аспекті. Методологічною основою дослідження слугуватимуть засади критичного дискурс-аналізу Н. Феркло. Відзначимо, що, використовуючи поняття „дискурс формалізму”, розуміємо під ним комплекс висловлювань у єдності з позамовними чинниками, в яких транслюються теоретичні пропозиції формалізму. Подібний підхід є трохи вужчим, ніж, наприклад, тлумачення словосполучення „дискурс модернізму”, запропоноване С. Павличко, але цілком відповідає інтерпретації поняття дискурсу Н. Феркло ${ }^{14}$. Maтеріалом для дослідження дискурсу українського формалізму є статті О. Полторацького (Як виробляти романи, 1928 р.), М. Семенка (Мистецтво як культ, 1924 р.), монографії Г. Майфета (Природа новелі, 1929 р.), Б. Якубського (Наука віршування, 1922 р.), розвідка М. Йогансена (Як будується оповідання. Аналіза прозових зразків, 1928 р.). Обраний текстовий матеріал загально подає парадигму реалізації українського літературознавчого формалізму (від академічних розвідок до статей в альтернативних часописах), а аналіз названих джерел спрямований насамперед на простеження паралелей, наявність яких свідчитиме про єдність дискурсу формалізму в Україні.

Якщо шукати спільний знаменник обраних для аналізу текстів, то його можна знайти на рівні, який Н. Феркло запропонував називати „впливом” висловлювань (the forces of utterances). Науковий дискурс, головною метою якого $\epsilon$ „отримання нового знання про світ та верифікація цього знання з допомогою методології сучасної науки"15, конструюється репрезентативними мовленнєвими актами (за класифікацією Д. Серля) з підтипами акту припущення й акту констатації ${ }^{16}$.

Однак дискурс українського формалізму репрезентований текстами, спрямованими на декларування та надання директив. Показовим є поєднання директивів та декларацій у текстах М. Семенка, О. Полторацького, М. Йогансена: „Маючи таку систему, вироблену на сучасній пролетарській практиці, ми обертаємо ї̈ в свою державну політику, і біля цього керма можемо сміливо дивитися в майбутнє”"17; „Ми пропонуємо другу формулу: не форма і зміст, а $i \partial e-$ ологія й фактура” 18 (курсив авт.); „Наші письменники, починаючи переходити до більших літературних жанрів, повинні подумати й про ті теоретичні засади, на яких базуватиметься цей більший літературний жанр”; „Ми хотіли б нагадати сучасному продуцентові романів ті основні композиційні засоби, що лягають в основу цього жанру” 19 ; „Я ж ніякої смерти не виголошую, а намагаюся поставити мистецтво на його місце. Не моя вина, коли це, належне йому, місце таке незавидне”; „Розпочинайте боротьбу; ломіть замки, висаджуйте шибки і забирайтеся в авторову лабораторію. Розкривайте скрині з його добром і здирайте одіж з манекенів. Докопуйтесь до методів його роботи, методів маскування, методів задурення, способів створити ілюзію"20. Подібний характер вислов-

${ }^{14}$ N. Fairclough, op. cit., p. 63.

${ }^{15}$ С. Карачаев в, Дискурсивность научного текста, Автореф. дис. канд. филол. наук, Нальчик 2009, [в:] Электронный ресурс: http://www.dissercat.com/content/diskursivnost-nauchnogoteksta $(10.10 .2013)$.

${ }^{16} \mathrm{H}$. Ш е в ц о в а, Научный дискурс и его лингвистическая прагматика, [в:] Электронный pecypc: http://www.uni-altai.ru/journal/vestnik/arhiw/n4_2002/1_sekz/schevzova.pdf (11.10.2013)

${ }^{17}$ М. С е м е н ко, Мистецтво як культ, [в:] „Червоний шлях” 1924, № 3, с. 222.

${ }^{18}$ Там само, с. 223.

${ }^{19}$ О . П о л т о р ац ь к и й, Як виробляти романи, [в:] „Нова Генерація”, 1928, № 5, с. 364.

${ }^{20}$ М. Й о г н с е н, Як будується оповідання. Аналіза прозових зразків, [в:] Електронний реcypc: http://gak.com.ua/articles/10 (14.10.2013). 
лювань М. Семенка, О. Полторацького, М. Йогансена цілком пояснюється належністю авторів до українського авангарду та їх роллю в літературному процесі 1920-х рр. Проте така спрямованість, хоча й імпліцитно виявлена, властива й академічним розвідкам Г. Майфета й Б. Якубського. Обидва автори наголошують на „лікнепівській” місії власних робіт і їх скеруванню на підвищення письменницької майстерності: мета Природи новелі Г. Майфета — „лябораторнокритичним шляхом сприяти підвищенню якости літературної продукції, прислужитися вищепозначеному “лікнепівському” завданню”21; Б. Якубський же у вступі до своєї розвідки говорить про можливість ії використання молодими аматорами поезії, наголошуючи на тому, що „останніми часами й нові форми поезії нашої й загальний розвиток науки віршування вимагають подібної праці" 22 . Подібна скерованість робіт свідчить про розхитування уявлень про місію науки як соціального інституту, адже тексти українського формалізму не тільки продукують знання, але й прагнуть вплинути на актуальний літературний процес. При цьому, якщо альтернативні тексти (М. Семенка, О. Полторацького, з певними зауваженнями і М. Йогансена) як декларації спрямовані на зміну статусу чи умов об'єктів уже самим успішним декларуванням ${ }^{23}$, то академічні роботи постають радше „спробами” внести зміни в стан речей, віднесеними на майбутнє ${ }^{24}$.

Опозицію до уявлень про місію науки як продуцента знань, а також прагнення внести зміни в модель статусно-рольової комунікації науки, пронизаної владними відношеннями, суворою ієрархічністю ${ }^{25}$, простежуємо й на рівні структури й граматики текстів українського формалізму. Звернемо увагу на назви обраних розвідок, що не вкладаються в рамки уявлень про назви наукових робіт: і Як будується оповідання, і Як виробляти романи, й навіть Природа новелі та Наука віршування мають виразний акцент на прикладному потенціалі текстів. Крім того, структура обраних для аналізу текстів не відповідає традиційним компонентам наукового дискурсу, що базується на таких мовленнєвих стратегіях його учасників: визначення проблемної ситуації, виділення предмету наукового аналізу, вивчення історії питання, формулювання гіпотези та мети дослідження, вибір методів, побудова моделей предмету вивчення, виклад результатів тощо ${ }^{26}$. Наближення до окресленої структури спостерігаємо в монографіях Г. Майфета і Б. Якубського, проте в обох розвідках бракує такого важливого елемента викладу в науковій розвідці, як висновки, але, висновки як структурний елемент є вагомими для розвідок М. Семенка, М. Йогансена, проте і їх не можна назвати викладом результатів дослідження (М. Семенко подає пронумерований список дій для „встановлення комуністичної політики в мистецтві”27, а М. Йогансен завершує виклад „натхненним” зверненням до авторів під заголовком „Борітеся — поборете”28).

Огляд історії вивчення проблеми, пояснення причин вибору методології також відсутні в статтях, що репрезентують український формалізм. Пояснення

${ }^{21}$ Г. М ай фе т, Природа новелі. Збірка друга, Харків 1929, с. 4.

22 Б. Яку б с ь и й, Наука віршування, Київ 2007, с. 21.

${ }_{23}$ Дж. Р. С ерль, Классификация иллокутивных актов, [в:] Электронный ресурс: http:// www.classes.ru/grammar/159.new-in-linguistics-17/source/worddocuments/iv2.htm (15.10.2013).

${ }^{24}$ Там же.

${ }^{25}$ А. О гу рц ов, Научный дискурс: власть и коммуникаиия (дополнительность двух традиций), [в:] Электронный ресурс: http://www.ihst.ru/projects/sohist/papers/ogur93sp.htm (13.10.2013).

${ }^{26} \mathrm{C}$. К а р ач а е в а, указ. источник.

${ }^{27}$ М. С е мен ко, зазн. джерело, с. 229.

${ }^{28} \mathrm{M}$. Йог ан с ен, зазн. джерело. 
подібних порушень у структурі розвідок, на нашу думку, слід шукати в “підважуванні" авторами аналізованих текстів базових цінностей науки, адже такі елементи структури наукового тексту, як огляд історії проблеми, вибір методології, виклад отриманих результатів постають підтвердженням достовірності отриманих результатів і підтримують „імідж” науки як продуцента достовірних знань. Ігнорування окреслених елементів свідчить про переслідування дослідниками іншої мети, прояснити яку допоможуть подальші спостереження над структурою текстів українського формалізму.

Спільною рисою для всіх обраних для аналізу текстів є увага до їхньої зовнішньої побудови, графічного оформлення: текст розвідок поділений на оптимальні для сприйняття за обсягом компоненти, абзаци за обсягом є невеликими, ключові тези виділені графічно (розрядка, нумерація положень). Крім того, для журнальних публікацій характерне винесення важливих тверджень в окремі абзаци, для більших за обсягом розвідок - наявність заголовків у кожної (навіть невеликої за обсягом) структурної частини. Подібна увага до членування тексту та його графічного подання може бути пояснена прагненням досягти максимальної результативності його сприйняття, відповідно, автори шукають баланс між складністю передаваної інформації (яку завжди викликає складність структури $^{29}$ ) та легкістю іiі сприйняття. Чітка структурованість в аналізованих текстах може бути пояснена бажанням авторів досягти максимальної ефективності в передаванні повідомлення, подолавши втрати інформаційного потенціалу повідомлення внаслідок шумів у каналі зв'язку (якщо звернутися до класичної моделі комунікації К. Шеннона), що було особливо актуальним в поліфонічному контексті української культури 1920-х рр.

Досягненню максимальної ефективності комунікації служать також засоби інтеграції текстів — когезія та когерентність. Ключовим засобом когезії в аналізованих розвідках виступають лексичні повтори, що особливо виразно простежується на межі абзаців у статтях, розділів - у монографіях. Так, у роботі Б. Якубського спостерігаємо „анонсування” предмету наступного розділу в останньому абзаці попереднього (див. розділи про ритмічне почуття, ритм, метр, віршування тощо ${ }^{30}$ ); подібна тактика простежується й у розвідці М. Йогансена, який повторює слова і словосполучення надмірно часто, що призводить до „стирання” їхнього сприйняття (автоматизації, якщо звертатися до формалістської термінології (наскрізні повторення словосполучень виробничий проиес, продукиійний проиес, доведене до абсурду нагромадження повторів слова мистецтвво в першій частині роботи). Г. Майфет у Природі новелі як засоби повтору вживає власні назви (див., напр., повторення імені Дж. Бокаччіо та назви його книги Декамерон). Вагомі лексичні повтори й у статті М. Семенка, що поєднуються з графічним виділенням повторюваних слів і словосполучень. Якщо в розвідці М. Иогансена надмір повторень призводить до ефекту абсурдності й спрямований на пародіювання виступів партійних діячів, то М. Ceменко вживає повтори, підтримуючи пародійовану М. Йогансеном риторику:

„Легко бачити, що при цих передумовах побуту, при таких засадах “творчости”, від цієї “творчости” зостануться ріжки та ніжки, бо коли немає творчости, то немає й мистецтва, і те, що хотять назвати пролетарським мистецтвом, буде остільки ж походити на мистецтво, як і пролетарська релігія на комунізм.

${ }^{29}$ М. Лотман, Структура художественного текста, [в:] Электронный ресурс: http:// on4a.narod.ru/lotman_struktura_teksta_web.pdf

${ }^{30}$ Б. Я ку б с ь к й , зазн. джерело, с. 56-57, с. 48-49, с. 70-71, с. 81. 
Значить, мистецтва, як емоціонального культу, який мав би инші методи організації, крім конструктивних і математичних, програм-максимум (комунізм), не знає. Мистецтва не буде.

Але мистецтвво $\epsilon$.

Тут приходить час оперувати аналогіями. Мистецтво $є$, але мистецтва не буде" 31 (курсив авт.).

Для статті ж О. Полторацького характерне використання анафор на початку абзаців (роман, нам потрібний, нас цікавить), що також не є характерним для суто наукового стилю викладу і може бути сприйняте як свідчення перетину наукового й художнього дискурсів, характерного для літературознавчих текстів російських формалістів ${ }^{32}$.

Когезія як формально-граматична єдність підтримується когерентністю, що охоплює, на думку М. Макарова, семантико-прагматичні аспекти смислової та діяльнісної зв'язності дискурсу ${ }^{33}$. Дослідник виділяє три виміри когерентності - глобальний, локальний і тематичний ${ }^{34}$. У межах поданої статті й обраного для аналізу матеріалу звернутися до глобальної когеренції дискурсу формалізму не маємо можливості, проте можемо осмислити тематичний та локальний її аспекти.

Простежити тематичну когерентність можна через аналіз повторюваних „мотивів” і „тем”, локальна ж когерентність у писемних текстах пов'язана 3 прагненням комунікантів реалізувати текстові цілі (подати необхідну фонову інформацію, навести приклад, запропонувати аргумент) ${ }^{35}$. Спільною тенденцією в обраних для аналізу текстах постає актуалізація фонової інформації: насамперед апеляція до контексту творення нової культури (соціальні фонові знання, відомі всім учасникам мовленнєвого акту ще до початку спілкування ${ }^{36}$ ), а також акцент на необхідності розробки літературознавчої теорії саме в українському контексті (колективні фонові знання, пов'язані з певною професі$\epsilon ю$, спеціальним знанням ${ }^{37}$ ). Повторне звернення до наведених вище цитат, що ілюстрували директиви та декларації в аналізованих розвідках, підтверджує, що перспективними реципієнтами аналізованих текстів повинні бути не члени наукової спільноти, чого можна очікувати від наукової розвідки, але молоді літератори. Особливо помітно це в розвідці Г. Майфета, який, судячи зі специфіки викладу, апелює до читачів, які тією або тією мірою дотичні до письменництва й мають загальні знання з історії літератури, але потребують докладнішої інформації щодо специфіки побудови новели, яку й надає дослідник.

До такого ж типу аудиторії апелює і Б. Якубський, який, як і Г. Майфет, зважає на зміну ступеня інформованості читача. Так, починаючи перший розділ Науки віршування з апеляції до впорядкованості світу (,УУ житті всесвіту панує певний лад, порядок. Сам всесвіт - упорядкована система. <...> Цей загальний лад, порядок, зветься ритмом - у широкому розумінні цього слова" (виділення авт. $)^{38}$, Б. Якубський наприкінці роботи звертається до читача, вже обі-

${ }^{31}$ М. Семенко, зазн. джерело, с. 227.

${ }^{32}$ А . Р а з у м о в а, Путь формалистов к художественной прозе, [в:] „Вопросы литературы”, 2004, № 3, c. 131-150.

${ }_{33}^{33}$ М. Макар о в, Основь теории дискурса, Москва 2003, с. 195.

${ }^{34}$ Там же, с. 195-196.

${ }^{35}$ Там же, с. 196.

${ }^{36}$ Н. В а лг и н а, Теория текста, [в:] Электронный pecypc: http://evartist.narod.ru/text14/04. htm\#_ftn1 (14.10.2013).

${ }^{37} \mathrm{H}$. В алгин а, Там же.

${ }^{38}$ Б. Я ку б с ь и й, зазн. джерело, с. 29. 
знаного з віршознавчою проблематикою (останній підрозділ починається так: „Серед різних типів строфічної будови в віршуванні існують такі, що мають суворо регламентовану постійну форму, стали певним віршованим каноном"з9). Таке ж поступове „залучення” читача до кола „професійних літераторів” спостерігаємо й у розвідках М. Йогансена, О. Полторацького, М. Семенка, у яких яскраво виявлений інший вимір когерентності - тематичний. Тематична когерентність найбільш виразно простежується в тому, що ключовим концептом текстів усіх трьох авторів є концепт вироблення / виробництва, що відповідає „духу” 1920-х рр.: у статті М. Семенка часто вживаними лексемами є практика, тактика, деструкція, конструкція, будування, акція тощо; М. Йогансен активно оперує словами будування, організація, конструювати, використовува$m u$, подібний ряд зустрічаємо й в О. Полторацького - виробництво, побудова, продукт тощо. Обертання навколо ключового концепту вироблення / виробниuзтва, на нашу думку, постає не просто результатом впливу контексту доби, але й може бути сприйняте як цілеспрямований акцент одновекторності власних пошуків з загальною риторикою та прагненням включити реципієнта (молодого автора насамперед) у процес творення нової української культури, змусити його дотримуватися принципу кооперації, особливо категорії відношення, що полягає в очікуванні адекватних кроків від партнера на кожному етапі спільних дій ${ }^{40}$.

Подібному „включенню” реципієнта до спільної діяльності сприяє апеляція до ще номінальної в 1920-х рр. тотальності творення нової культури, що 3 часом трансформується в тоталітарний тиск на культуру. Наслідування риторики виступів партійних діячів (особливо - у М. Семенка, О. Полторацького, М. Йогансена) яскраво простежується на рівні лексичному: в статтях перерахованих авторів поширені метафори, епітети, зацентровані навколо концепту боротьби, що стане ключовим у пізнішій соцреалістичній свідомості ${ }^{41}$ : „Розпочинайте боротьбу; ломіть замки, висаджуйте шибки і забирайтеся в авторову лабораторію. Розкривайте скрині з його добром і здирайте одіж з манекенів. Докопуйтесь до методів його роботи, методів маскування, методів задурення, способів створити ілюзію”42; „Роман проблемний характерний для доби переходової, саме тоді, коли класа ще не перемогла і бореться за гегемонію. Ми перемогли, перед нами нема „проблем” у лапках. На передній план висувається єдину проблему - виховати нову людину”43. Користуючись концепцією „новомови”, висунутої М. Гловіньським ${ }^{44}$, перелік спільних рис між аналізованими текстами й соцреалістичним способом комунікації можна було б розширити, відзначивши домінування паратактичних конструкцій, використання просторічних метафор, маніпулювання евфемізмами й гіперболами, гру двозначністю слів тощо. Використання поетичних прийомів, проте може бути пояснене не тільки впливом риторики партійних виступів, але й апеляцією до можливостей художньої творчості, що має більший інформаційний потенціал, ніж наукове повідомлення ${ }^{45}$. Звернення до образного потенціалу слова простежується й у специфіці ви-

\footnotetext{
${ }^{39}$ Там само, с. 165

${ }^{40} \Gamma$. Гр ай с, Логика и речевое общение, [в:] Электронный ресурс: // http://kant.narod.ru/grice. htm\#_ftn1 (10.10.2013).

${ }^{41}$ W. To m a si k, Polska powieść tendencyjna, Wrocław 1988, c. 45.

${ }^{42} \mathrm{M}$. Й ог ан с ен, зазн. джерело.

${ }^{43} \mathrm{O}$. Полт о раць к и й, зазн. джерело, с. 365.

${ }^{44}$ M. Gło wińs ki, Nowomowa i ciagi dalsze, Kraków 2009, s. 11-33.

${ }^{45}$ Г. А. Гол и цы н, Образ как кониентратор информации, [в:] Синергетическая парадигма. Нелинейное мышление в науке и искусстве, Москва 2002, с. 183-185.
} 
користовуваної термінології. В усіх аналізованих текстах (поза хіба що розвідками Б. Якубського і М. Семенка, в яких формалістські пропозиції є об’єктом полеміки) зустрічаємо активне звернення до введених формалістами в літературознавчий обіг понять (прийом, матеріал, функиія, морфологія, поновлення тощо), що за своєю природою є предтермінами, адже мають тимчасовий характер, нестійкість форми, не відповідають вимогам загальноприйнятості та стилістичної нейтральності ${ }^{46}$. Водночас, зважаючи на те, що предтермінам властива тенденція переходити в терміни, можемо розмірковувати про претензію формалістів на науковість, отже, про їхнє перебування саме в дискурс-будові науки. Таким чином, наявність елементів партійної риторики та художніх прийомів у текстах українських формалістів можемо пояснити специфікою їх інтердискурсивності - виходом за межі дискурс-будови науки та зверненням до дискурсів інших соціальних інститутів.

Підсумовуючи, можемо зробити висновок про наявність спільних рис, що можуть бути підставою для твердження про існування єдності дискурсу українського формалізму. У розвідках перерахованих авторів спостерігаємо полеміку $з$ дискурс-будовою науки на різних рівнях, що виявляється у вживанні декларацій та директив, порушенні структури, характерної для наукових текстів, використанні предтермінів, художніх прийомів та залученні засобів партійної риторики. Крім того, для проаналізованих текстів характерна специфічна структурованість із графічним виділенням ключових положень, актуалізація соціальних фонових знань, акцент на принципі кооперації. Окреслені особливості дають змогу визначити напрям змін у дискурс будові-науки, пропонований українським формалізмом. За допомогою текстів, що є максимально легкими для сприйняття й максимально насиченими інформацією, підтримують загальноприйняту риторику та відповідають контексту будування нової культури в 1920-х рр., український формалізм пропонував власну візію дискурс-будови науки, що із засобу продукування знання перетворюється на знаряддя культурних трансформацій. Зважаючи на недостатньо широкий текстовий матеріал та зосередження лише на ключових особливостях аналізованих розвідок, зроблений висновок пропонуємо вважати гіпотезою, що потребує більш докладної аргументації.

${ }^{46}$ И. В о ро б ь е в а, Экономические прототермины в русском языке XV-XVI вв., Автореф. дис. канд. филол. наук, Москва 2009, с. 10. 